\title{
Mercury induces inflammatory mediator release from human mast cells
}

\author{
Duraisamy Kempuraj ${ }^{1}$, Shahrzad Asadi ${ }^{1}$, Bodi Zhang ${ }^{1}$, Akrivi Manola', Jennifer Hogan', Erika Peterson², \\ Theoharis C Theoharides ${ }^{1,3,4,5^{*}}$
}

\begin{abstract}
Background: Mercury is known to be neurotoxic, but its effects on the immune system are less well known. Mast cells are involved in allergic reactions, but also in innate and acquired immunity, as well as in inflammation. Many patients with Autism Spectrum Disorders (ASD) have "allergic" symptoms; moreover, the prevalence of ASD in patients with mastocytosis, characterized by numerous hyperactive mast cells in most tissues, is 10-fold higher than the general population suggesting mast cell involvement. We, therefore, investigated the effect of mercuric chloride $\left(\mathrm{HgCl}_{2}\right)$ on human mast cell activation.

Methods: Human leukemic cultured LAD2 mast cells and normal human umbilical cord blood-derived cultured mast cells (hCBMCs) were stimulated by HgCl2 (0.1-10 $\mu \mathrm{M})$ for either $10 \mathrm{~min}$ for beta-hexosaminidase release or $24 \mathrm{hr}$ for measuring vascular endothelial growth factor (VEGF) and IL-6 release by ELISA.

Results: $\mathrm{HgCl}_{2}$ induced a 2-fold increase in $\beta$-hexosaminidase release, and also significant VEGF release at 0.1 and $1 \mu \mathrm{M}\left(311 \pm 32 \mathrm{pg} / 10^{6}\right.$ cells and $443 \pm 143 \mathrm{pg} / 10^{6}$ cells, respectively) from LAD2 mast cells compared to control cells $\left(227 \pm 17 \mathrm{pg} / 10^{6}\right.$ cells, $\left.\mathrm{n}=5, \mathrm{p}<0.05\right)$. Addition of $\mathrm{HgCl}_{2}(0.1 \mu \mathrm{M})$ to the proinflammatory neuropeptide substance $\mathrm{P}(\mathrm{SP}, 0.1 \mu \mathrm{M})$ had synergestic action in inducing VEGF from LAD2 mast cells. $\mathrm{HgCl}_{2}$ also stimulated significant VEGF release $\left(360 \pm 100 \mathrm{pg} / 10^{6}\right.$ cells at $\left.1 \mu \mathrm{M}, \mathrm{n}=5, \mathrm{p}<0.05\right)$ from hCBMCs compared to control cells $\left(182 \pm 57 \mathrm{pg} / 10^{6}\right.$ cells), and IL-6 release $\left(466 \pm 57 \mathrm{pg} / 10^{6}\right.$ cells at $\left.0.1 \mu \mathrm{M}\right)$ compared to untreated cells $(13 \pm 25$ $\mathrm{pg} / 10^{6}$ cells, $\left.\mathrm{n}=5, \mathrm{p}<0.05\right)$. Addition of $\mathrm{HgCl}_{2}(0.1 \mu \mathrm{M})$ to SP $(5 \mu \mathrm{M})$ further increased IL-6 release.
\end{abstract}

Conclusions: $\mathrm{HgCl}_{2}$ stimulates VEGF and IL-6 release from human mast cells. This phenomenon could disrupt the blood-brain-barrier and permit brain inflammation. As a result, the findings of the present study provide a biological mechanism for how low levels of mercury may contribute to ASD pathogenesis.

\section{Background}

Heavy metals such as mercury result in neurological injury that may lead to developmental defects, peripheral neuropathies, and enhanced neurodegenerative changes [1]. Mercurials may be found in various drugs, in bleaching creams, antiseptics, disinfectants, as preservatives in cosmetics, tooth pastes, lens solutions, vaccines, contraceptives and immunotherapy solutions, fungicides, herbicides and in dental fillings, as well as in fish such as tuna due to water pollution [2]. Mercury can cause immune, sensory, neurological, motor, and

\footnotetext{
* Correspondence: theoharis.theoharides@tufts.edu

'Molecular Immunopharmacology and Drug Discovery Laboratory, Department of Pharmacology and Experimental Therapeutics, Tufts University School of Medicine and Tufts Medical Center, Boston, MA 02111,
} USA

(c) 2010 Kempuraj et al; licensee BioMed Central Ltd. This is an Open Access article distributed under the terms of the Creative Commons Attribution License (http://creativecommons.org/licenses/by/2.0), which permits unrestricted use, distribution, and reproduction in any medium, provided the original work is properly cited. behavioral dysfunction similar to those associated with Autism Spectrum Disorders (ASD) [2]. The possible role of mercury used as preservative in vaccines [2] has been debated extensively, but most epidemiological studies do not support a causal association between vaccines and autism [3-7]. However, $87 \%$ of children included in the US Vaccine Adverse Event Reporting System (VAERS) had ASD [8]. Moreover, a paper based on computerized medical records in the Vaccine Safety Data-link concluded there was "significantly increased rate ratios for ASD with mercury exposure from thiomerosal-containing vaccines" [9]. Mercury has been shown to induce proliferation and cytokine production from $\mathrm{T}$ lymphocytes [10]. Mercuric chloride $\left(\mathrm{HgCl}_{2}\right)$ in nontoxic doses induces the release of histamine and cytokines, such as IL-4 and tumor necrosis factor-alpha (TNF- $\alpha$ ), from a 
murine mast cell line and from mouse bone marrowderived cultured mast cells [11]. $\mathrm{HgCl}_{2}(100 \mu \mathrm{M})$ also enhances immunoglobulin E-mediated mediator release from human basophils [12], and histamine release from a rat basophil cell line (RBL-2H3) [13].

We, therefore, investigated whether $\mathrm{HgCl}_{2}$ could stimulate human mast cells, an action that could be enhanced in subjects who already have an atopic background.

\section{Methods}

$\mathrm{HgCl}_{2}$ was obtained from Fluka Chemical Corp. (Milwaukee, WI) and was diluted in Dulbecco's phosphate buffered saline (DPBS, GIBCO, Grand Island, NY) on the day of the experiments.

\section{Human mast cell culture}

LAD2 and human umbilical cord blood-derived cultured mast cells (hCBMCs) were cultured as previously described $[14,15]$. Umbilical cord blood was collected as approved by the Tufts Medical Center's (Boston, MA) Investigation Review Board in tubes containing $10 \mathrm{U} / \mathrm{ml}$ heparin, blood was diluted 1:2 with DPBS, GIBCO) containing $2 \mathrm{mM}$ ethylenediaminetetraacetic acid (Sigma, St. Louis, MO). Non-phagocytic mononuclear cells were separated by density-gradient centrifugation using Lymphocyte Separation Medium (LSM) from Organon Teknika Corp. (Durham, NC). The isolation of hematopoietic stem and progenitor cells $\left(\mathrm{CD} 34^{+}\right)$was performed by positive selection of AC133-expressing cells by magnetic-associated cell sorting (MACS) using an AC133 cell isolation kit (Milltenyi Biotec, Auburn, CA) as reported previously $[15,16]$. CD34 ${ }^{+}$cells were suspended in AIM-V Medium (GIBCO BRL), supplemented with 100 to 200 $\mathrm{ng} / \mathrm{ml}$ recombinant human stem cell factor ( $\mathrm{rhSCF}$, Amgen, Thousand Oaks, CA), 50 ng/ml IL-6 (Millipore, Temecula, CA) and cultured for 12 to 16 weeks. During this culture period, the cells were washed with DPBS every week and resuspended using fresh culture medium. The purity of hCBMCs was evaluated by immunocytochemical staining for tryptase as previously described [15]. Mast cell viability was determined by Trypan blue $(0.3 \%)$ exclusion method. LAD2 cells cultured over 10 days and hCBMCs cultured over 12 weeks were used for the experiments.

\section{Histamine assay}

LAD2 or hCBMCs cells were washed with DPBS and mast cell media, once in each. Cell suspensions $\left(5 \times 10^{4}\right.$ cells per tube, $500 \mu \mathrm{l} /$ sample) were preincubated with either the neuropeptide substance $\mathrm{P}(\mathrm{SP}, 0.1-2 \mu \mathrm{M})$ or anti-IgE $(10 \mu \mathrm{g} / \mathrm{ml})$ as positive controls, or $\mathrm{HgCl}_{2}(1-10$ $\mu \mathrm{M})$ for $30 \mathrm{~min}$. After the reaction, the cells were centrifuged and the supernatant fluid was collected.

Histamine levels were assayed using EIA histamine kit (\# IM2015; Immunotech, Beckman Coulter Company,
France) as per the directions. Histamine release was calculated as percent of total.

\section{$\boldsymbol{\beta}$-Hexosaminidase assay}

$\beta$-Hexosaminidase release, as an index of mast cell degranulation, was assayed using a fluorometric assay as previously reported [17]. Briefly, $\beta$-hexosaminidase activity in the supernatant fluid and cell lysates (LAD2 cells, $0.5 \times 10^{5} /$ tube, were lysed with $1 \%$ Triton X-100 to measure residual cell-associated $\beta$-hexosaminidase) were incubated with substrate solution (p-nitrophenyl-Nacetyl- $\beta$-D-glucosaminide from Sigma, St Louis, MO) in $0.1 \mathrm{M}$ citrate buffer $(\mathrm{pH} 4.5)$ for $60 \mathrm{~min}$ at $37^{\circ} \mathrm{C}$. The reaction was terminated by the addition $0.2 \mathrm{M} \mathrm{NaOH} /$ $0.2 \mathrm{M}$ glycine. Absorbance was read at $405 \mathrm{~nm}$ in an enzyme-linked immunosorbent assay reader, and the results are expressed as the percentage of $\beta$-hexosaminidase activity released over the total.

\section{Cytokine assay}

LAD2 cells or hCBMCs were washed with DPBS, sterile Tyrode's buffer, and plain culture medium, once in each, and were suspended in complete culture medium without IL-6 (for hCBMCs). The LAD 2 cells or hCBMCs $\left(2 \times 10^{5}\right.$ cells/well $\left./ 200 \mu \mathrm{l}\right)$ were plated in 96well, flat-bottom Falcon cell culture plates (Becton Dickinson) and were pre-incubated for $15 \mathrm{~min}$ at $37^{\circ} \mathrm{C}$ in a $5 \% \mathrm{CO}_{2}$ incubator. The cells were then incubated with either neuropeptide SP $(0.1-2 \mu \mathrm{M})$ or $\mathrm{HgCl}_{2}(1-10 \mu \mathrm{M})$ for 24 hours at $37^{\circ} \mathrm{C}$. Control cells were treated with equal volumes of only the respective culture medium. After the reaction time, plates were centrifuged and the supernatant medium was gently collected from the wells and stored at $-80^{\circ} \mathrm{C}$ until the cytokines were measured by enzyme-linked immunosorbent assay (ELISA) using a commercial kit (Quantikine, R\&D Systems, Minneapolis, $\mathrm{MN}$ ), as reported previously [18]. The minimum detectable levels of VEGF and IL- 6 were $5 \mathrm{pg} / \mathrm{ml}$. Cell viability was assessed at 1 hour and at 24 hours using the Trypan blue exclusion method.

\section{Statistical analysis}

All conditions were performed in triplicate, and all experiments were repeated five times $(n=5)$. Results are presented as mean \pm SD. Data from two conditions, such as stimulated and control samples, were compared using the Unpaired 2-tailed Student's t-test. Significance of comparisons is denoted by $\mathrm{p}<0.05$.

\section{Results}

\section{Effects of $\mathrm{HgCl}_{2}$ on mast cell viability}

LAD2 mast cells and hCBMCs were incubated with $\mathrm{HgCl}_{2}$ for 1 hour or for 24 hours in their respective media, and cell viability was assessed by Trypan blue 
exclusion. $\mathrm{HgCl}_{2}$ reduced viability of LAD2 mast cells in culture medium only slightly (10\%), only at concentration of $10 \mu \mathrm{M}$, and only after 24 hours of incubation ( $\mathrm{n}=3$, Fig. $1 \mathrm{~A}) . \mathrm{HgCl}_{2}$ reduced viability of hCBMCs by $25 \%$ at concentration of $10 \mu \mathrm{M}$ after 24 hours of incubation $(\mathrm{n}=5$; Fig. 1B).

\section{Effects of $\mathrm{HgCl}_{2}$ on LAD2 mast cell histamine release}

We first tried to study the effect of $\mathrm{HgCl}_{2}$ on mast cell histamine release. We assayed histamine release from LAD2 mast cells and hCBMCs after incubation with $\mathrm{HgCl}_{2}(1-10 \mu \mathrm{M})$ for another $30 \mathrm{~min}$ at $37^{\circ} \mathrm{C}$ in Tyrode's buffer. Addition of $\mathrm{HgCl}_{2}$ for $30 \mathrm{~min}$ induced statistically significant histamine release from hCBMCs, compared to control cells, at $\mathrm{HgCl}_{2}$ concentrations of 0.1 and $1 \mu \mathrm{M}$. However, as the results were inconsistent due to interference of $\mathrm{HgCl}_{2}$ with the histamine assay, we do not present them. Instead, we investigated the effect of $\mathrm{HgCl}_{2}$ on the release of $\beta$-hexosaminidase, another secretory granule marker that is released in parallel with histamine. Only $10 \mu \mathrm{M} \mathrm{HgCl}_{2}$ was able to induce a 2 -fold increase in $\beta$-hexosaminidase release (Fig. 2A, $\mathrm{n}=5, \mathrm{p}<0.05$ ).

\section{Effects of $\mathrm{HgCl}_{2}$ on LAD2 mast cell VEGF release}

We then investigated whether $\mathrm{HgCl}_{2}$ could stimulate release of proinflammatory mediators from mast cells. LAD2 mast cells released significantly more VEGF at $\mathrm{HgCl}_{2}$ concentrations of 0.1 and $1 \mu \mathrm{M}\left(311 \pm 32 \mathrm{pg} / 10^{6}\right.$ cells and $443 \pm 143 \mathrm{pg} / 10^{6}$ cells, respectively, compared to $227 \pm 17 \mathrm{pg} / 10^{6}$ cells for control cells, $\mathrm{p}<0.05$, Fig. 2B). $\mathrm{HgCl}_{2}(0.1 \mu \mathrm{M})$ had a statistically significant synergistic effect on LAD2 mast cell VEGF release (693 \pm 102 pg/106 cells) when added with SP $(0.1 \mu \mathrm{M})$ (Fig. 2B). Combinations of higher concentrations of $\mathrm{HgCl}_{2}$ and SP did not induce any additional VEGF release.

\section{Effects of $\mathrm{HgCl}_{2}$ on hCBMC VEGF and IL- 6 release}

$\mathrm{HgCl}_{2}(1 \mu \mathrm{M})$ also induced release of significantly more VEGF $\left(182 \pm 57 \mathrm{pg} / 10^{6}\right.$ cells $)$ from hCBMCs $(\mathrm{n}=5, \mathrm{p}<$ $0.05)$ compared to control cells $\left(360 \pm 100 \mathrm{pg} / 10^{6}\right.$ cells $)$ (Fig. 3A).
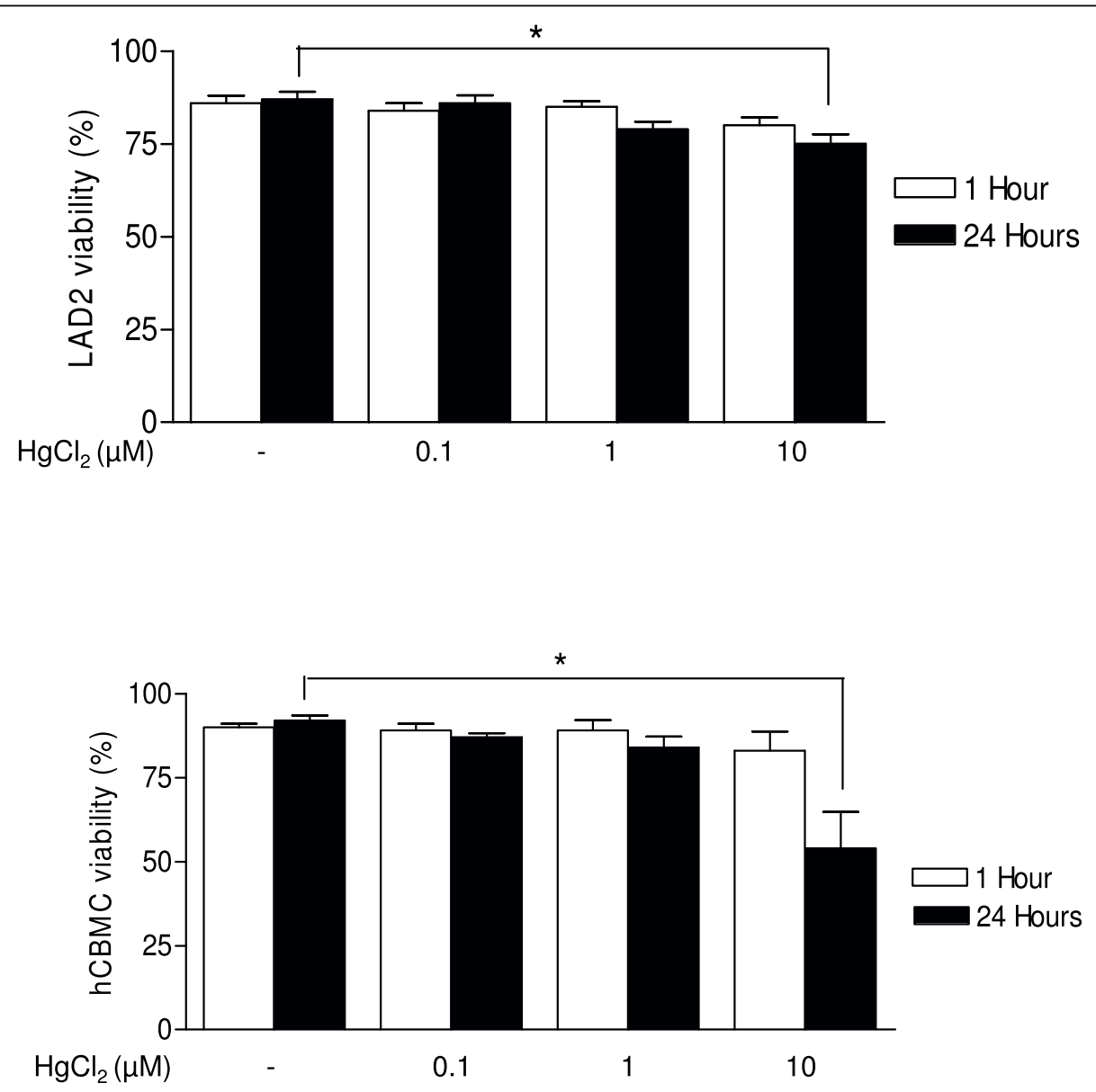

Figure 1 Effects of $\mathrm{HgCl}_{2}$ on (A) LAD2 mast cells and (B) hCBMCs viability assayed by supravital staining with Trypan blue. LAD2 mast cells and hCBMCs were incubated with $\mathrm{HgCl}_{2}$ one hour or 24 hours at $37^{\circ} \mathrm{C}$ and the viability was assayed $(n=3)$. 


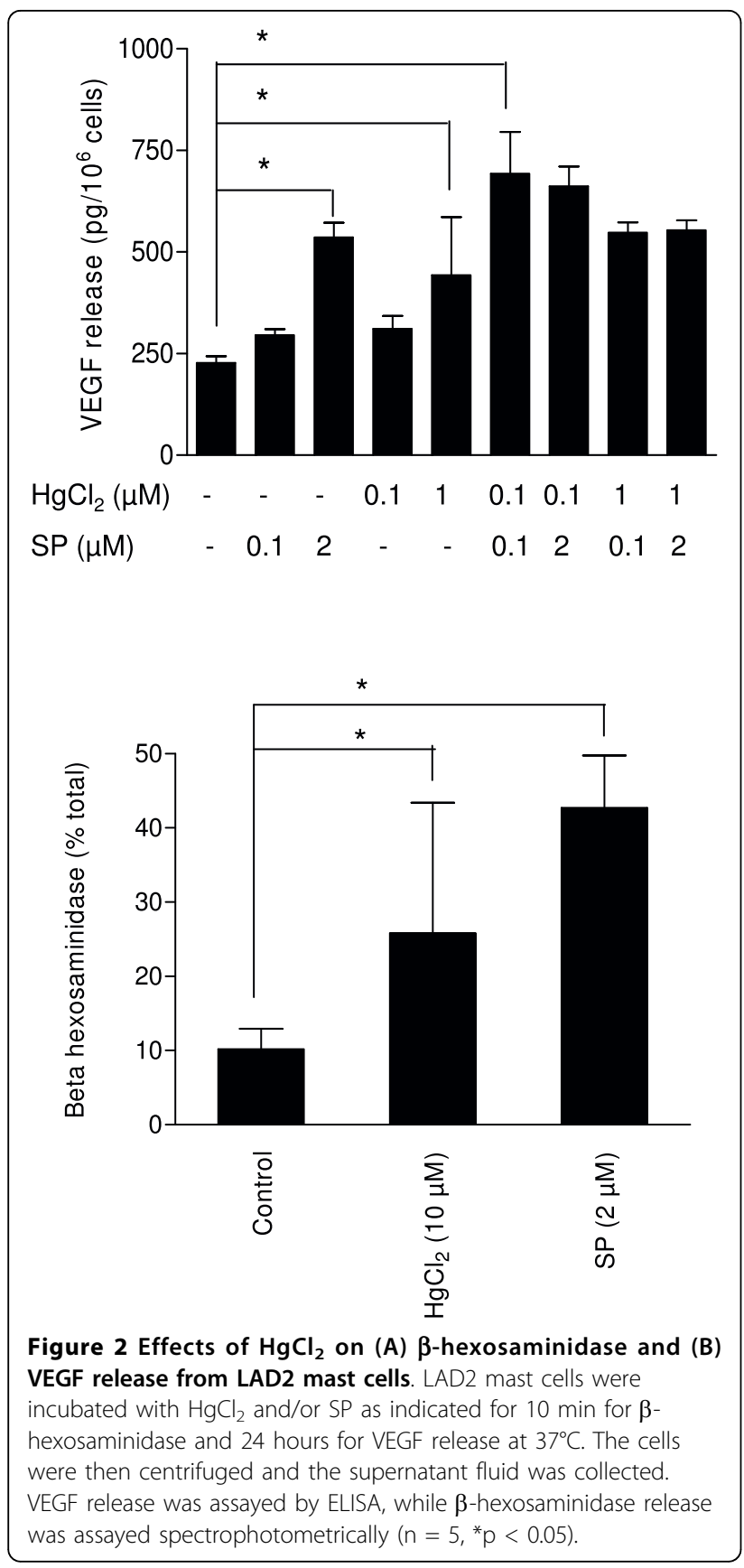

LAD2 mast cells cannot synthesize IL-6. We, therefore, investigated the effect of $\mathrm{HgCl}_{2}$ on IL-6 release from hCBMCs. $\mathrm{HgCl}_{2}(0.1$ and $1 \mu \mathrm{M})$ significantly induced IL- 6 release $\left(466 \pm 57 \mathrm{pg} / 10^{6}\right.$ cells and $204 \pm$ $47 \mathrm{pg} / 10^{6}$ cells, respectively) compared to untreated control cells $\left(13 \pm 25 \mathrm{pg} / 10^{6}\right.$ cells, $\mathrm{n}=5$, Fig. $\left.3 \mathrm{~B}\right)$. SP (5 $\mu \mathrm{M})$, used as a positive control, also significantly increased IL-6 release $\left(609 \pm 57 \mathrm{pg} / 10^{6}\right.$ cells) from hCBMCs. Addition of $\mathrm{HgCl}_{2}(0.1)$ with SP $(5 \mu \mathrm{M})$ further increased IL- 6 release to $745 \pm 117 \mathrm{pg} / 10^{6}$ cells (Fig. 3B).

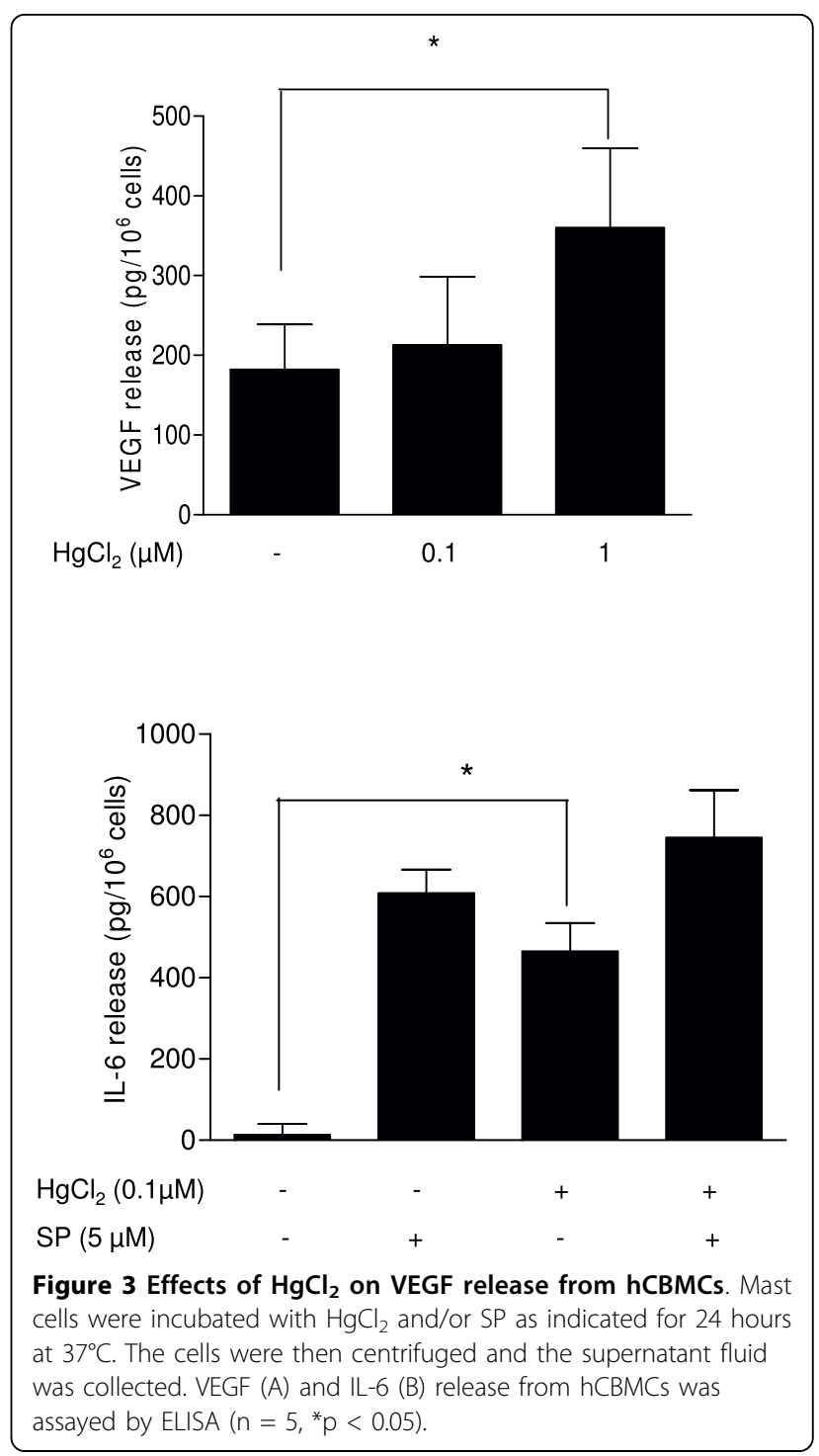

\section{Discussion}

This is the first report to our knowledge showing that inorganic mercury in concentrations as low as $0.1 \mu \mathrm{M}$ can induce VEGF and IL-6 release from human cultured mast cells. We also report for the first time that mercury has a significant synergistic effect with SP $(0.1 \mu \mathrm{M})$ on VEGF release; this amount of VEGF release is higher than what has previously been reported for hCBMCs [19]. One paper has reported that $\mathrm{HgCl}_{2}$ can induce release of histamine from primary lung and human leukemic mast cells (HMC-1 cells), but only at toxic levels of $0.33 \mathrm{mM}$ [20]. Here we show that $\mathrm{HgCl}_{2}$ induces $\beta$ hexosaminidase release, but only at a concentration of $10 \mu \mathrm{M}$. Mercury $(10 \mu \mathrm{M})$ has previously been shown to induce release of $\beta$-hexosaminidase, IL- 4 and TNF- $\alpha$ from a murine mast cell line and from mouse bone marrow-derived cultured mast cells; the secretion of 
cytokines mediated by $\mathrm{HgCl}_{2}$ is additive to that which follows FcepsilonRI-induced mast cell activation [11]. In contrast, $\mathrm{HgCl}_{2}$ does not have an effect on its own on release of histamine and IL-4 from human basophil, but only enhances allergic release at concentrations of 1 and $10 \mu \mathrm{M}$ [12]. This is also true for IL-4 release from rat mast cells [21]. Clinical symptoms of mercury poisoning may be expected at blood levels of $1 \mu \mathrm{M}$ [12]. However, brain mast cells may react to lower mercury concentrations, especially in vulnerable patient subpopulations.

Mast cells, by virtue of their location in the skin, respiratory tract, and gastrointestinal system are potential targets for environmental agents with immunotoxic effects [22]. Mast cells are critical not only for allergic reactions, but also important in both innate and acquired immunity [23], as well as in inflammation [24]. In view of the fact that a subgroup of ASD patients have allergy symptoms that do not appear to be triggered by IgE, it is noteworthy that mast cells can be stimulated by non-allergic triggers originating in the gut or the brain [24], especially neuropeptides such as SP [25] and neurotensin (NT) [26]. Once activated, mast cells secrete numerous vasoactive, neurosensitizing and proinflammatory molecules that are relevant to ASD; these include histamine, proteases, VEGF, prostaglandin $\mathrm{D}_{2}$, as well as cytokines such as IL-6 [24]. In particular, mast cells can secrete VEGF [27,28], an isoform of which is vasodilatory [29] and is over expressed in delayed hypersensitivity reactions [30]. In fact, mast cells can release VEGF [31], IL-6 [32] and other mediators "selectively" without degranulation [33]. Such mediators could disrupt the gut-blood and blood-brain barriers (BBB) permitting brain inflammation [34]. It is important to note that mercury can cross the $\mathrm{BBB}$ through a transport mechanism that can lead to significant brain concentrations, and that can persist for prolonged periods of time $[2,35]$. Activated brain mast cells can disrupt the $\mathrm{BBB}[36,37]$ and further increase brain mercury levels.

The mechanisms of heavy metal neurotoxicity are not fully understood. Mercury increases cytosolic calcium levels in PC12 cells [38], and thimerosal does so in thymus lymphocytes [39]. Mercury may also increase cellular oxidative stress since neurons are highly susceptible to reactive oxygen species (ROS) and neuronal mitochondria are especially vulnerable to oxidative damage [40]. In fact, the primary dietary source of neurotoxic mercury compounds is via the ingestion of methylmercury from fish, which has been previously linked to neurological damage [41].

Mercury's activation of mast cell inflammatory mediator release may enhance allergic reactions in atopic individuals and exacerbate IgE-dependent diseases [12]. Allergic symptomatology is often present in ASD patients
[34], and a survey of children with ASD in Italy reported that the strongest association was with a history of allergies [42]. Moreover, a recent study reported increased atopic diseases, as well as elevated serum IgE and eosinophils in Asperger patients [43]. In a National Survey of Children's Health, parents of autistic children reported symptoms of allergies more often than other children, with food allergies showing the greatest difference [44]. A case series study also reported higher rate of food allergies in ASD children [45]. In one study, 30\% of autistic children $(\mathrm{n}=30)$ had a history of atopy as compared to $2.5 \%$ of age-matched "neurologic controls" $(\mathrm{n}=30)$, but there was no difference in serum IgE or in skin prick tests to 12 common antigens [46], implicating triggers other than IgE. In another study, ASD patients did not have increased incidence of allergic asthma or allergic dermatitis [42], but this study included only ASD patients that were positive to RAST/skin testing. Finally, a preliminary report indicated that the prevalence of ASD may be 10-fold higher [47] than the general population (1/100 children) in mastocytosis patients [48], characterized by increased number of hyperactive mast cells in many tissues, with symptoms that include allergies, food intolerances and "brain fog" [49,50].

Some epidemiological studies have failed to find a significant relationship between mercury exposure from vaccines and autism [3-7]. Nevertheless, $87 \%$ of children included in the US Vaccine Adverse Event Reporting System (VAERS) have ASD [8]. Moreover, a paper based on computerized medical records in the Vaccine Safety Datalink concluded there was "significantly increased rate ratios for ASD with mercury exposure from Thimerosal-containing vaccines" [9]. Also, there are a series of epidemiological studies conducted in the USA that have found significant associations between environmental sources of mercury exposure and ASDs [51]. In addition, patients with severe ASD have evidence of significantly increased urinary porphyrins consistent with mercury intoxication [52-55]. Mercury toxicity may also affect critical methylation pathways in vulnerable cells [56].

ASD are a group of pervasive developmental disorders that include autistic disorder, Asperger's disorder, and atypical autism - also known as pervasive developmental disorder-not otherwise specified (PDD-NOS). These are neurodevelopmental disorders diagnosed in early childhood [57]. They are characterized by various degrees of dysfunctional communication and social skills, repetitive and stereotypic behaviors, as well as attention, cognitive, learning and sensory defects $[57,58]$. ASD cases have increased more than 10-fold during the last decade to a prevalence of $1 / 100$ children $[44,57,59]$. However, there is no known distinct pathogenesis, there are no biomarkers, and there is no effective treatment [60]. 
ASD may result from a combination of genetic/biochemical susceptibility and epigenetic exposure to environmental factors, including reduced ability to excrete mercury and/or exposure to mercury at critical developmental periods $[2,56]$. A number of papers have suggested that ASD may be associated with immune dysfunction [61], while a recent review made the case that ASD may be a neuroimmune disorder involving mast cell activation [34].

\section{Conclusions}

The results of the present study support the biological plausibility of how mercury could contribute to ASD pathogenesis by inducing VEGF and IL-6 release from mast cells, and as a result disrupt the BBB and thus permit brain inflammation. Further studies should investigate the effect of mercury and thimerosal alone or together with allergic and non-immune triggers.

\section{Abbreviations \\ ASD: Autism Spectrum Disorders; (DPBS): Dulbecco's phosphate buffered saline; hCBMCs: human umbilical cord blood-derived cultured mast cells; ELISA: enzyme-linked immunosorbent assay; $\mathrm{HgCl}_{2}$ : mercury chloride; PDD- NOS: pervasive developmental disorder-not otherwise specified; (NT): neurotensin; (SP): Substance P; rhSCF: recombinant human stem cell factor; VAERS: Vaccine Adverse Event Reporting System; VEGF: vascular endothelial growth factor}

\section{Acknowledgements}

This work was funded in part by the Safe Minds (Huntington Beach, CA) and the Defeat Autism Now Coalition (San Diego, CA), as well as Theta Biomedical Consulting and Development Co., Inc. (Brookline, MA). Christos Damianos Kalogeromitros participated in some aspects of this work as part of his IB project at Athens College, Greece.

\section{Author details}

Molecular Immunopharmacology and Drug Discovery Laboratory, Department of Pharmacology and Experimental Therapeutics, Tufts University School of Medicine and Tufts Medical Center, Boston, MA 02111, USA. ${ }^{2}$ Department of Obstetrics \& Gynecology, Maternal-Fetal Medicine, Tufts University School of Medicine and Tufts Medical Center, Boston, MA 02111, USA. ${ }^{3}$ Department of Biochemistry, Tufts University School of Medicine, Boston, MA 02111, USA. ${ }^{4}$ Department of Internal Medicine, Tufts University School of Medicine and Tufts Medical Center, Boston, MA 02111, USA. ${ }^{5}$ Department of Psychiatry, Tufts University School of Medicine and Tufts Medical Center, Boston, MA 02111, USA.

\section{Authors' contributions}

This study is based on an original idea of TCT. TCT and DK wrote the manuscript. DK and SA carried out the cytokine, $\beta$-hexosaminidase and histamine assays. JH, AM, BZ carried out the viability assays and some mediator assays. EP provided umbilical cord blood. All authors have read and approved the manuscript.

\section{Competing interests}

TCT is on the Scientifc Advisory Board of The Mastocytosis Society. TCT is the inventor of US patents No. $6,624,148 ; 6,689,748 ; 6,984,667$ and EPO 1365777 , which cover methods and compositions of mast cell blockers in neuroinflammatory conditions, as well as US patent application No.12/ 534,571 for diagnosis and treatment of ASD.

Received: 3 December 2009 Accepted: 11 March 2010 Published: 11 March 2010
References

1. Monroe RK, Halvorsen SW: Environmental toxicants inhibit neuronal Jak tyrosine kinase by mitochondrial disruption. NeuroToxicol 2009, 30:589-598.

2. Geier DA, King PG, Sykes LK, Geier MR: A comprehensive review of mercury provoked autism. Indian J Med Res 2008, 128:383-411.

3. Stehr-Green P, Tull P, Stellfeld M, Mortenson PB, Simpson D: Autism and thimerosal-containing vaccines: lack of consistent evidence for an association. Am J Prev Med 2003, 25:101-106.

4. D'Souza Y, Fombonne E, Ward BJ: No evidence of persisting measles virus in peripheral blood mononuclear cells from children with autism spectrum disorder. Pediatrics 2006, 118:1664-1675.

5. DeStefano F: Vaccines and autism: evidence does not support a causal association. Clin Pharmacol Ther 2007, 82:756-759.

6. Baker JP: Mercury, vaccines, and autism: One controversy, three histories. Am J Public Health 2008, 98:244-253.

7. Fombonne E: Thimerosal disappears but autism remains. Arch Gen Psychiatry 2008, 65:15-16.

8. Woo EJ, Ball R, Landa R, Zimmerman AW, Braun MM: Developmental regression and autism reported to the Vaccine Adverse Event Reporting System. Autism 2007, 11:301-310.

9. Young HA, Geier DA, Geier MR: Thimerosal exposure in infants and neurodevelopmental disorders: an assessment of computerized medical records in the Vaccine Safety Datalink. J Neurol Sci 2008, 271:110-118.

10. Jiang $\mathrm{Y}, \mathrm{Moller} \mathrm{G}$ : In vitro effects of $\mathrm{HgCl} 2$ on murine lymphocytes. I. Preferable activation of CD4+ T cells in a responder strain. J Immunol 1995, 154:3138-3146

11. Dastych J, Walczak-Drzewiecka A, Wyczolkowska J, Metcalfe DD: Murine mast cells exposed to mercuric chloride release granule-associated $\mathrm{N}$-acetyl-beta-D-hexosaminidase and secrete IL-4 and TNF-alpha. J Allergy Clin Immunol 1999, 103:1108-1114.

12. Strenzke N, Grabbe J, Plath KE, Rohwer J, Wolff HH, Gibbs BF: Mercuric chloride enhances immunoglobulin E-dependent mediator release from human basophils. Toxicol Appl Pharmacol 2001, 174:257-263.

13. Suzuki Y, Yoshimaru T, Yamashita K, Matsui T, Yamaki M, Shimizu K: Exposure of $\mathrm{RBL}-2 \mathrm{H} 3$ mast cells to $\mathrm{Ag}(+)$ induces cell degranulation and mediator release. Biochem Biophys Res Commun 2001, 283:707-714.

14. Kirshenbaum AS, Akin C, Wu Y, Rottem M, Goff JP, Beaven MA et al: Characterization of novel stem cell factor responsive human mast cell lines LAD 1 and 2 established from a patient with mast cell sarcoma/ leukemia; activation following aggregation of FcepsilonRI or FcgammaRI. Leuk Res 2003, 27:677-682.

15. Kempuraj D, Saito $H$, Kaneko A, Fukagawa $K$, Nakayama M, Toru $H$, et al: Characterization of mast cell-committed progenitors present in human umbilical cord blood. Blood 1999, 93:3338-3346.

16. Kempuraj D, Papadopoulou NG, Lytinas M, Huang M, KandereGrzybowska K, Madhappan B, et al: Corticotropin-releasing hormone and its structurally related urocortin are synthesized and secreted by human mast cells. Endocrinology 2004, 145:43-48.

17. Puri N, Roche PA: Mast cells possess distinct secretory granule subsets whose exocytosis is regulated by different SNARE isoforms. Proc Natl Acad Sci USA 2008, 105:2580-2585.

18. Kempuraj D, Madhappan B, Christodoulou S, Boucher W, Cao J, Papadopoulou $\mathrm{N}$, et al: Flavonols inhibit proinflammatory mediator release, intracellular calcium ion levels and protein kinase $C$ theta phosphorylation in human mast cells. Br J Pharmacol 2005, 145:934-944.

19. Kempuraj D, Tagen M, lliopoulou BP, Clemons A, Vasiadi M, Boucher W, et al: Luteolin inhibits myelin basic protein-induced human mast cell activation and mast cell dependent stimulation of Jurkat $\mathrm{T}$ cells. $\mathrm{Br} \mathrm{J}$ Pharmacol 2008, 155:1076-1084

20. Schedle A, Samorapoompichit P, Fureder W, Rausch-Fan XH, Franz A, Sperr WR, et al: Metal ion-induced toxic histamine release from human basophils and mast cells. J Biomed Mater Res 1998, 39:560-567.

21. Wu Z, Pearson A, Oliveira D: Characterization of cis-regulatory elements conferring mercury-induced interleukin- 4 gene expression in rat mast cells: a role for signal transducer and activator of transcription 6 and TATA box binding sites. Immunology 2009, 127:530-538.

22. Paus R, Theoharides TC, Arck PC: Neuroimmunoendocrine circuitry of the 'brain-skin connection'. Trends Immunol 2006, 27:32-39. 
23. Galli SJ, Kalesnikoff J, Grimbaldeston MA, Piliponsky AM, Williams CM, Tsai M: Mast cells as "tunable" effector and immunoregulatory cells: recent advances. Annu Rev Immunol 2005, 23:749-786.

24. Theoharides TC, Kalogeromitros D: The critical role of mast cell in allergy and inflammation. Ann NY Acad Sci 2006, 1088:78-99.

25. Janiszewski J, Bienenstock J, Blennerhassett MG: Picomolar doses of substance $P$ trigger electrical responses in mast cells without degranulation. Am J Physiol 1994, 267:C138-C145.

26. Carraway $\mathrm{R}$, Cochrane $\mathrm{DE}$, Lansman JB, Leeman $\mathrm{SE}$, Paterson BM, Welch $\mathrm{HJ}$ : Neurotensin stimulates exocytotic histamine secretion from rat mast cells and elevates plasma histamine levels. J Physiol 1982, 323:403-414.

27. Boesiger J, Tsai M, Maurer M, Yamaguchi M, Brown LF, Claffey KP, et al: Mast cells can secrete vascular permeability factor/vascular endothelial cell growth factor and exhibit enhanced release after immunoglobulin E-dependent upregulation of Fce receptor I expression. J Exp Med 1998, 188:1135-1145.

28. Grutzkau A, Kruger-Krasagakes S, Baumeister H, Schwarz C, Kogel H, Welker $P$, et al: Synthesis, storage and release of vascular endothelial growth factor/vascular permeability factor (VEGF/VPF) by human mast


1998, 9:875-884

29. Laham RJ, Li J, Tofukuji M, Post M, Simons M, Sellke FW: Spatial heterogeneity in VEGF-induced vasodilation: VEGF dilates microvessels but not epicardial and systemic arteries and veins. Ann Vasc Surg 2003, 17:245-252.

30. Brown LF, Olbricht SM, Berse B, Jackman RW, Matsueda G, Tognazzi KA, et al: Overexpression of vascular permeability factor (VPF/VEGF) and its endothelial cell receptors in delayed hypersensitivity skin reactions. $J$ Immunol 1995, 154:2801-2807.

31. Cao J, Papadopoulou N, Kempuraj D, Boucher WS, Sugimoto K, Cetrulo CL, et al: Human mast cells express corticotropin-releasing hormone $(\mathrm{CRH})$ receptors and $\mathrm{CRH}$ leads to selective secretion of vascular endothelial growth factor. J Immunol 2005, 174:7665-7675.

32. Kandere-Grzybowska K, Letourneau R, Kempuraj D, Donelan J, Poplawski S, Boucher W, et al: IL-1 induces vesicular secretion of IL-6 without degranulation from human mast cells. J Immunol 2003, 171:4830-4836.

33. Theoharides TC, Kempuraj D, Tagen M, Conti P, Kalogeromitros D: Differential release of mast cell mediators and the pathogenesis of inflammation. Immunol Rev 2007, 217:65-78.

34. Theoharides TC, Kempuraj D, Redwood L: Autism: an emerging 'neuroimmune disorder' in search of therapy. Exp Opinion on Pharmacotherapy 2009, 10:2127-2143.

35. Burbacher TM, Shen DD, Liberato N, Grant KS, Cernichiari E, Clarkson T: Comparison of blood and brain mercury levels in infant monkeys exposed to methylmercury or vaccines containing thimerosal. Environ Health Perspect 2005, 113:1015-1021.

36. Esposito $P$, Gheorghe D, Kandere K, Pang X, Conally R, Jacobson S, et al: Acute stress increases permeability of the blood-brain-barrier through activation of brain mast cells. Brain Res 2001, 888:117-127.

37. Esposito P, Chandler N, Kandere-Grzybowska K, Basu S, Jacobson S, Connolly $\mathrm{R}$, et al: Corticotropin-releasing hormone $(\mathrm{CRH})$ and brain mast cells regulate blood-brain-barrier permeability induced by acute stress. $J$ Pharmacol Exp Ther 2002, 303:1061-1066.

38. Rossi AD, Larsson O, Manzo L, Orrenius S, Vahter M, Berggren PO, et al: Modifications of $\mathrm{Ca} 2+$ signaling by inorganic mercury in PC12 cells. FASEB J 1993, 7:1507-1514.

39. Elferink JG: Thimerosal: a versatile sulfhydryl reagent, calcium mobilizer, and cell function-modulating agent. Gen Pharmacol 1999, 33:1-6.

40. Kidd PM: Neurodegeneration from mitochondrial insufficiency: nutrients, stem cells, growth factors, and prospects for brain rebuilding using integrative management. Altern Med Rev 2005, 10:268-293.

41. Harris $\mathrm{HH}$, Pickering IJ, George GN: The chemical form of mercury in fish. Science 2003, 301:1203.

42. Persico AM, Sacco R, Curatolo P, Manzi B, Lenti C, Saccani M, et al: Isolation of principal components in autistic disorder symptomatology and their association with biological endophenotypes. Proc Society for Neuroscience, Washington DC 2008, Abstract \#446.20.

43. Magalhaes ES, Pinto-Mariz F, Bastos-Pinto S, Pontes AT, Prado EA, Deazevedo LC: Immune allergic response in Asperger syndrome. J Neuroimmunol 2009, 1-2:108-112.
44. Gurney JG, McPheeters ML, Davis MM: Parental report of health conditions and health care use among children with and without autism: National Survey of Children's Health. Arch Pediatr Adolesc Med 2006, 160:825-830

45. Jyonouchi H, Geng L, Cushing-Ruby A, Quraishi H: Impact of innate immunity in a subset of children with autism spectrum disorders: a case control study. J Neuroinflammation 2008, 5:52

46. Bakkaloglu B, Anlar B, Anlar FY, Oktem F, Pehlivanturk B, Unal F, et al: Atopic features in early childhood autism. Eur J Paediatr Neurol 2008, 12:476-479.

47. Theoharides TC: Autism spectrum disorders and mastocytosis. Int J Immunopathol Pharmacol 2009, 22:859-865.

48. Kogan MD, Blumberg SJ, Schieve LA, Boyle CA, Perrin JM, Ghandour RM et al: Prevalence of parent-reported diagnosis of autism spectrum disorder among children in the US, 2007. Pediatrics 2009, 5:1395-1403.

49. Castells M: Mast cell mediators in allergic inflammation and mastocytosis. Immunol Allergy Clin North Am 2006, 26:465-485.

50. Akin C, Valent $P$, Escribano L: Urticaria pigmentosa and mastocytosis: the role of immunophenotyping in diagnosis and determining response to treatment. Curr Allergy Asthma Rep 2006, 6:282-288.

51. Palmer RF, Blanchard S, Stein Z, Mandell D, Miller C: Environmental mercury release, special education rates, and autism disorder: an ecological study of Texas. Health Place 2006, 12:203-209.

52. Geier DA, Kern JK, Garver CR, Adams JB, Audhya T, Nataf R, et al: Biomarkers of environmental toxicity and susceptibility in autism. $J$ Neurol Sci 2008, 280:101-108.

53. Geier DA, Geier MR: A prospective study of mercury toxicity biomarkers in autistic spectrum disorders. J Toxicol Environ Health A 2007, 70:1723-1730.

54. Adams JB, Romdalvik J, Ramanujam VM, Legator MS: Mercury, lead, and zinc in baby teeth of children with autism versus controls. J Toxicol Environ Health A 2007, 70:1046-1051.

55. Desoto MC, Hitlan RT: Blood levels of mercury are related to diagnosis of autism: a reanalysis of an important data set. J Child Neurol 2007, 22:1308-1311.

56. Deth R, Muratore C, Benzecry J, Power-Charnitsky VA, Waly M: How environmental and genetic factors combine to cause autism: A redox/ methylation hypothesis. NeuroToxicol 2008, 29:190-201.

57. Fombonne E: Epidemiology of pervasive developmental disorders. Pediatr Res 2009, 65:591-598.

58. Johnson CP, Myers SM: Identification and evaluation of children with autism spectrum disorders. Pediatrics 2007, 120:1183-1215

59. Theoharides TC, Angelidou A, Alysandratos K-A: Neonatal mast cell activation and autism. Brain, Behavior, Immunity 2010.

60. Theoharides TC, Doyle R, Francis K, Conti P, Kalogeromitros D: Nove therapeutic targets for autism. Trends Pharmacol Sci 2008, 29:375-382.

61. Ashwood P, Wills S, Water Van de J: The immune response in autism: a new frontier for autism research. J Leukoc Biol 2006, 80:1-15.

doi:10.1186/1742-2094-7-20

Cite this article as: Kempuraj et al:: Mercury induces inflammatory mediator release from human mast cells. Journal of Neuroinflammation 2010 7:20.

\section{Submit your next manuscript to BioMed Central and take full advantage of:}

- Convenient online submission

- Thorough peer review

- No space constraints or color figure charges

- Immediate publication on acceptance

- Inclusion in PubMed, CAS, Scopus and Google Scholar

- Research which is freely available for redistribution 